\title{
Fetal hydropsia: challenges in etiologies
}

\author{
Hidropsia fetal: desafios nas etiologias \\ Hidropsia fetal: desafíos en las etiologías
}

\begin{abstract}
Introduction: Fetal hydrops is defined as the presence of abnormal fluid collections in two or more extravascular fetal compartments and body cavities. There are about 150 different underlying causes known today potentially leading to this fetal alteration. Objective: To analyze the etiologies involved in the occurrence of cases of fetal hydrops. Methods: A systematic literature review was carried out using the MedLine, Pubmed and Scielo databases, from 2015 to 2021, using the expressions: "fetal, hydrop, etiologies." Discussion: Fetal hydrops is divided into immune and non-immune. Immune results from anemia secondary to erythroblastosis by alloimmunization, so when there is maternal exposure to fetal antigens, it generates an immune response that results in the production of antibodies. History of blood transfusions, previous births, trauma and a history of alloimmunization are characterized as risk factors. Thus, immunoprophylaxis with anti-D immunoglobulin is indicated for all RhD negative pregnant women, with RhD positive male partner, with abundant fetal maternal hemorrhage during childbirth or events with potential sensitizer in the prenatal period. Conclusion: For an effective treatment, it is essential to identify the type of fetal hydrops in the patient and then the etiology of the disease, which is quite variable in Non-Immune Fetal Hydrops.
\end{abstract}

Keywords: Fetal; Hydrop; Etiologies.

\section{Resumo}

Introdução: A hidropisia fetal é definida como a presença de coleções de fluidos anormais em dois ou mais compartimentos extravasculares fetais e do corpo cavidades. Existem cerca de 150 diferentes causas subjacentes conhecidas hoje potencialmente levando a esta alteração fetal. Objetivo: Analisar as etiologias envolvidas na ocorrência de casos de hidropsia fetal. Métodos: Realizada uma revisão sistemática da literatura por meio das bases de dados MedLine, Pubmed e Scielo, entre o período de 2015 a 2021, utilizando as expressões: "Hidropsia, fetal, etiologias." Discussão: Divide-se a hidropsia fetal em imune e não imune. A imune resulta da anemia secundária a eritroblastose por aloimunização, dessa forma quando há uma exposição materna a antígenos fetais, gera uma resposta imunológica que resulta na produção de anticorpos. Antecedentes de transfusões sanguíneas, partos prévios, traumas e história prévia de aloimunização são caracterizados como fatores de risco. Dessa forma, a imunoprofilaxia com imunoglobulina anti-D está indicada para todas grávidas $\mathrm{RhD}$, com progenitor masculino RhD positivo, com hemorragia materno fetal abundante durante o parto ou eventos com potencial sensibilizador no período pré natal. Conclusão: Para um tratamento efetivo, é fundamental a identificação do tipo de hidropsia fetal do paciente e, em seguida, a etiologia da doença, a qual é bastante variável na Hidropsia Fetal Não Imune.

Palavras-chave: Hidropsia; Fetal; Etiologias. 


\begin{abstract}
Resumen
Introducción: La hidropesía fetal se define como la presencia de colecciones anormales de líquido en dos o más compartimentos fetales extravasculares y cavidades corporales. Hay alrededor de 150 causas subyacentes diferentes conocidas hoy en día que potencialmente conducen a esta alteración fetal. Objetivo: Analizar las etiologías involucradas en la ocurrencia de casos de hidropesía fetal. Métodos: Se realizó una revisión bibliográfica sistemática utilizando las bases de datos MedLine, Pubmed y Scielo, de 2015 a 2021, utilizando las expresiones: "fetal, hidrop, etiologías". Discusión: La hidropesía fetal se divide en inmunes y no inmunes. La inmunidad resulta de la anemia secundaria a eritroblastosis por aloinmunización, por lo que cuando hay exposición materna a antígenos fetales, se genera una respuesta inmune que resulta en la producción de anticuerpos. Los antecedentes de transfusiones de sangre, nacimientos previos, traumatismos y antecedentes de aloinmunización se caracterizan como factores de riesgo. Así, la inmunoprofilaxis con inmunoglobulina anti-D está indicada para todas las gestantes $\mathrm{RhD}$, con progenitor masculino $\mathrm{RhD}$ positivo, con abundante hemorragia materno-fetal durante el parto o eventos con potencial sensibilizante en el período prenatal. Conclusión: Para un tratamiento eficaz, es fundamental identificar el tipo de hidropesía fetal en el paciente y luego la etiología de la enfermedad, que es bastante variable en la hidropesía fetal no inmunitaria.
\end{abstract}

Palabras clave: Fetal; Hidrop; Etiologías.

\title{
1. Introduction
}

Fetal hydrops is defined as the presence of abnormal fluid collections in two or more extravascular fetal compartments and body cavities. It is characterized by generalized skin thickness $>5 \mathrm{~mm}$, placental enlargement, including ascites, pleural effusions, pericardial effusion, and generalized skin edema (Bellini et al., 2015). It occurs in approximately 1 in 3,000 pregnant women and is diagnosed by ultrasound during prenatal care (Mardy et al., 2019). There are about 150 different underlying causes known today potentially leading to this fetal alteration. (Hartge et al., 2015)

In this context, it is also worth emphasizing that fetal hydrops is an accumulation of fluids in the fetus, it can occur due to two pathophysiological processes: immune or non-immune. The Immune Fetal Hydrops that was caused by Rhesus, occurs due to $\mathrm{Rh}$ incompatibility, also called isoimmunization, it happens when an Rh-negative mother comes into contact with Rh-positive fetal erythrocytes, her body forms antibodies that cross the placenta and cause hemolysis of the fetal erythrocytes (Bellini et al., 2012). However, there was a significantly reduced incidence after the introduction of RhD immunoglobulin as prophylaxis of isoimmunization in the 1960 (Bellini et al., 2012).

On the other hand, non-immune fetal hydrops (NIHF) constitutes up to $90 \%$ of all described cases of fetal hydrops in the world, it occurs due to the interruption of the flow and absorption of fetal fluid due to anemia, cardiovascular anomalies, increased permeability vascular, altered lymphatic flow and several other pathologies, having a significant fetal compromise that is associated with high rates of perinatal mortality and neonatal morbidity. (Brock et al., 2016)

Thus, it is essential to understand the etiology of fetal hydrops so that pregnancies can be actively managed, anticipating neonatal care needs, implementing urgent treatments and advising families on the prognosis and risk of recurrence (Mardy et al., 2019). The aim of this study is to analyze the etiologies involved in the occurrence of cases of fetal hydrops.

\section{Methodology}

This is a systematic literature review, and the research was carried out by 5 authors from May to July 2021. The search platforms PubMed, Medical Literature, Analysis and Retrieval System Online (MEDLINE) and Scielo search platforms were used, with 15 articles selected from 2015 to 2020, using the present descriptors (DECs and MeSH) - keywords "fetal, hydrop and etiologies" carried out in English and Spanish. In addition, abstracts, duplicates, letters to journal editors, gray literature and book chapters were excluded, as well as those that did not present the subject covered in manuscript in the title, abstract or text. 


\section{Results and Discussion}

\section{Causes of Immune Fetal Hydrops:}

Immune fetal hydrops, resulting from anemia secondary to erythroblastosis caused by alloimmunization, until the 1960s, was the main cause of fetal hydrops. With the advent, in 1969, of anti-D immunoprophylaxis, non-immune fetal hydrops became more prevalent. However, there is a relative increase in the incidence of immune fetal hydrops by antibodies called minor, that is, low frequency antibodies, and therefore, in suspected cases of immune fetal hydrops, they should be investigated (Silva et al., 2005).

Of these minor antigens, the Kell blood group system is the most prevalent, accounting for approximately $10 \%$ of cases of immune-mediated anemia (Silva et al., 2005). Still, immune fetal hydrops can arise in a context where immunological and non-immunological causes coexist or where multiple antigens are simultaneously implicated (Lee et al., 2016).

Fetal hydrops will arise in a state of alloimmune hemolytic disease, most often when there is a blood $\mathrm{Rh}$ incompatibility between the mother and the fetus, particularly if due to maternal fetal hemorrhage, blood transfusions, previous pregnancies or previous births. When there is maternal exposure to these fetal antigens, an immune response can be triggered, in which clonal B lymphocytes that recognize the fetal antigens as a "foreign body" will be activated, leading to the production of IgM. If there is a new exposure to these antigens, there is a new activation and proliferation of lymphocytes, now with $\operatorname{Ig} G$ production (Ek et al., 2017).

There are some protective and risk factors for the development of immune fetal hydrops. For reasons still unknown, even after repeated stimuli, a third of women are unable to produce anti-D antibodies, as well as ABO incompatibility seems to reduce the risk of sensitization by $90 \%$ for individuals in group A and by $50 \%$ in group B (ABCMED, 2020). Regarding risk factors, without a doubt, history of blood transfusions is the one with the greatest impact, but we could also mention previous surgeries or births, hematological diseases and surgical removal of the placenta (Songdej et al., 2017).

The diagnostic process must begin with a detailed evaluation, which includes family history, previous obstetric history, traumatic history, occurrence of immunization or hydrops in previous pregnancies. In order to differentiate the two types of hydrops, it is necessary to resort to complementary tests, such as an obstetric Doppler ultrasound, in order to investigate all the gestational parameters. In immune fetal hydrops, ascites and pericardial effusion are the earliest detected signs, followed, eventually, by placental hypertrophy and skin edema. In addition, the investigation should include blood group and $\mathrm{Rh}$ phenotype, indirect Coombs test, search for irregular agglutinins and serology (Ek et al., 2017).

In short, the destruction of fetal cells contributes to the excessive accumulation of fluid in the baby. To prevent this type of situation from occurring, $\mathrm{Rh}$ immunoglobulin is administered to Rh-negative mothers when they reach the 28th week of gestation or up to 72 hours after delivery for mothers who give birth to Rh-positive babies. Therefore, immunoprophylaxis with anti-D immunoglobulin is indicated for all $\mathrm{RhD}$ pregnant women, with $\mathrm{RhD}$ positive male parent, with abundant maternal fetal hemorrhage during childbirth or events with potential sensitizing in the prenatal period (Bellini et al., 2015).

\section{Causes of Non-immune Fetal Hydrops}

Non-immune fetal hydrops occurs in 2 out of 1000 babies born alive, which shows that even with all the advances related to medical care and as fetal therapies, the mortality of newborns with this characteristic is quite high, ranging from 43 to $57,6 \%$, and occurs due to the basic influence of gestational age at birth and the cause of non-immune fetal hydrops (Mardy et al., 2019; Bellini et al., 2012).

Non-immune fetal hydrops can occur at two different times: before 24 weeks of gestation when it is usually associated with chromosomal abnormalities, such as: aneuploidy, deletion, duplication or genetic mutation, or; after 24 weeks of gestation it is usually associated with anomalies that interfere with the fetoplacental circulation (Yuan,2017). 


\section{Cardiovascular Disorders}

In the past, the most common cause of fetal hydrops was hydrops associated with erythroblastosis, but this configuration has changed and today the most common causes are cardiovascular pathologies, corresponding to about a quarter of all cases of non-immune fetal hydrops, in this group the anomalies structural and arrhythmias are the causes that stand out (Oztunc et al., 2016; Steurer et al., 2017; Yuan, 2017; Désilets et al., 2013; SMFM, 2015).

Structural anomalies can lead to compromised venous return or other dysfunction and result in fetal hydrops, these anomalies may be mild and not necessarily be the primary cause of hydrops (Mardy et al., 2019). There are some pathologies that can present with non-immune fetal hydrops, such as cardiac rhabdomyomas associated with tuberous sclerosis, or associated with it, such as arthrogryposis, Barth's Syndrome, Noonam and Costello's Syndrome, type VII mucopolysaccharidosis (Mardy et al., 2019). In the context of 22q11 microdeletion syndrome, truncus arteriosus, and aortic arch interruption can also be found associated with non-immune hydrops (Mardy et al., 2019).

Among the cardiac arrhythmias that can lead to non-immune fetal hydrops, it is possible to mention: Costello, Barth, long Qt and Wolff-Parkinson White syndromes (Mardy et al., 2019).

On the other hand, Klippel-Trenaunay-Weber syndrome, syndromes related to RASA1 and segmental overgrowth syndromes associated with PIK3CA, are the syndromes that are more rarely associated with non-immune fetal hydrops (Mardy et al., 2019).

\section{Chromosomal Syndromes}

Chromosomal anomalies, with emphasis on Down Syndrome and Turner Syndrome, are revealed as frequent causes of Non-Immune Fetal Hydrops (Bellini et al., 2009). Turner Syndrome is the main trigger of lymphangioma - a congenital malformation of the lymphatic system - typical of NIHF, which - marked by a disharmony between the systemic venous network and the lymphatic system - can lead to the onset of NIHF (Alpman et al., 2009). With regard to trisomy 21, there is evidence of possible occurrences of neonatal leukemic conditions, which can lead to a case of Non-Immune Fetal Hydrops (Malin et al., 2009).

Furthermore, NIHF may originate from other aneuploidies, especially trisomies 13 and 18, in addition to triploidies. It is seen that, in most cases, fetuses with aneuploidies that developed NIHF had defective cardiovascular formations (Malin et al., 2009).

\section{Hematological Disorders}

Hematological disorders are one of the most common causes of non-immune fetal hydrops, accounting for 4 to $12 \%$ of cases. There are several causes of anemia, they can be genetic, infections, vascular malformations and fetal-maternal hemorrhage (Mardy et al., 2019; Désilets et al. 2013).

The presence of anemia is suggested when it is observed that the peak systolic velocity of the middle cerebral artery is elevated, reaching 1.5 multiples of the median (MoM) or more for the gestational age (Mardy et al., 2019).

The most common hematologic disorder is alpha thalassemia (Mardy et al., 2019; SMFM, 2015). Other disorders are Bart Hemoglobin syndrome (loss of $4 \alpha$-globin genes), hemoglobin $\mathrm{H}$ disease (loss of $3 \alpha$-globin genes), transient abnormal myelopoiesis may present with fetal anemia, and NIHF in trisomy on chromosome 21 (Mardy et al., 2019). Other genetic disorders that can lead to anemia and NIHF are Diamond Blackfan anemia, pyruvate kinase deficiency, and congenital dyserythropoietic anemias (Mardy et al., 2019). 


\section{Infectious Diseases}

Another common cause of hydrops is intrauterine infections (4 to 15\% of cases), and the most frequent are parvovirus B19 infection and secondary anemia (Désilets et al. 2013). Diseases such as fetal toxoplasmosis, syphilis, cytomegalovirus and chickenpox may present as hydrops fetalis, associated with other findings hepatomegaly, splenomegaly or ascites (Désilets et al. 2013).

In these cases, hydrops develops as a result of multiple organ failure or generalized endothelial damage (Poeschmann et al., 1991).

\section{Intrathoracic Masses}

The presence of masses within the thoracic cavity may be related to the occurrence of NIHF, highlighting fetal hydrothorax pictures (Cavoretto et al. 2008). This, in turn, associated with the picture of fetal hydrops - both immune and nonimmune - is characterized by congestion and a generalized accumulation of fluid (Sanders, 2002).

Intrathoracic masses, in general, can lead to NIHF due to the possibility of occlusion and, therefore, hindering venous return (Randenberg, 2010).

\section{Placental Disorders}

The main lesions and placental damage closely linked to Non-Immune Fetal Hydrops are amniotic bands, which can lead to lymphedema, and chorioangiomas, the latter being frequent in 1\% of newborns (Randenberg, 2010). Placental chorioangioma is a placental tumor, which is usually benign. This neoplasm, when consuming the nutrition and oxygenation destined, in theory, to the fetus, can cause the appearance of generalized edema and, therefore, characterizing a picture of NIHFsee the extensive cardiac overload (Mauad Filho et al. 2002).

Another anomaly at the placental level responsible for the emergence of NIHF is the Feto-Fetal Transfusion Syndrome. This, through anomaly of collateral circulations in the placenta, generates a disharmony of blood flow in the placentas of, above all, monochorionic twin pregnancies, that is, the two identical twins who share the same placenta. In more critical situations of the syndrome, twins or just one child can develop hydrops, see the increase in blood pressure and an increase in blood volume, with emphasis on the fetus that receives this blood from the anastomosis (Van Den Wijngaard et al., 2007).

\section{Genitourinary and Kidney Anomalies}

Genitourinary and renal anomalies are rarely found associated with non-immune fetal hydrops (2\% to 3\% of cases) (Mardy et al., 2019). In congenital nephrosis, hyperechoic and enlarged kidneys and fetal alpha - elevated maternal serum protein are observed, which may result in fetal hypoproteinemia, decreased oncotic pressure and, ultimately, non-immune fetal hydrops (Mardy et al., 2019).

Studies have shown that Fraser syndrome can manifest with renal agenesis and non-immune fetal hydrops. Nonimmune fetal hydrops has been described in association with Bartter's syndrome (Mardy et al., 2019).

In Meckel Gruber syndrome and childhood polycystic kidney disease with non-immune fetal hydrops, enlarged and multicystic kidneys are observed (Mardy et al., 2019).

\section{Gastrointestinal Anomalies}

Gastrointestinal abnormalities are rare with non-immune fetal hydrops ( $0.5 \%$ to $4 \%$ of cases) (Mardy et al., 2019). It is believed that the mechanisms of action for hydrops associated with gastrointestinal disorders are venous congestion, 
decreased liver function, hypoalbuminemia and intrahepatic proliferation of metabolites (Mardy et al., 2019). Among these anomalies are diaphragmatic hernia, midgut volvulus, gastrointestinal obstruction, jejunal atresia, malrotation of the intestines and meconium peritonitis (SMFM, 2015). Obstruction of venous return due to intra-abdominal masses can cause non-immune fetal hydrops, and decreased colloid osmotic pressure and hypoproteinemia can be caused by gastrointestinal obstruction and infarction (SMFM, 2015). Liver pathologies (cirrhosis, liver necrosis, cholestasis, polycystic liver disease and biliary atresia) may be associated with non-immune fetal hydrops due to hypoproteinemia (SMFM, 2015). Liver hemangioma cases may also occur as a cause of non-immune fetal hydrops, possibly due to the arteriovenous shunt resulting in heart problems (SMFM, 2015).

Lysosomal storage disorders appear as hepatosplenomegaly (due to accumulation of metabolites) and isolated ascites (Mardy et al., 2019). Hepatomegaly has also been reported in association with nonimmune fetal hydrops and trisomy 21, probably due to transient myeloproliferative disorder, and has also been reported concomitantly with skeletal and hematological disorders (Mardy et al., 2019). Duodenal atresia can be seen in trisomy 21 and fetal omphalocele with Beckwith Wiedemann syndrome or aneuploidy (Mardy et al., 2019).

\section{Others}

Among other less frequent but important causes of NIHF, skeletal dysplasias can be addressed, which are marked by conformational alterations and at the level of cartilage and/or bone components. It is believed that, to compensate for the volumetric reduction in the bone marrow and, therefore, a deficit in its function, there is an increase in the livers through an exponential increase in blood cell precursors. This fact can lead to excessive and dysfunctional vessel occlusion and constriction, a fact that can lead to generalized edema (Randenberg, 2010).

Metabolic errors associated with certain genetic factors, moreover, may be linked to cases of Non-Immune Fetal Hydrops, which may be transient or an isolated picture of protein (ascitic) fluid accumulation inside the abdomen. The most notable genetic disorder triggering NIHF are the lysosomal storage diseases (LPDs), which, due to the failure of several lysosomal enzymes, there is an accumulation of protein content in various tissues and systemic organs (Whybra et al, 2012).

\section{Use of Medications}

The use of certain drugs by the mother can trigger hydrops, one of these drugs is Sulfasalazine and Mesalazine, a drug prescribed for the treatment of maternal inflammatory bowel diseases, such as Crohn's disease and ulcerative colitis (Ek et al., 2017). This drug has a series of side effects, ranging from headaches and tinnitus to hematological effects (leukopenia and thrombocytopenia) (Ek et al., 2017). During pregnancy, the use of this medication should be monitored because it belongs to Category C (Ek et al., 2017). Although there are not many reports associating the use of this medication. to side effects in pregnant women, what can be said is that they can trigger fetal anemia and consequently non-immune fetal hydrops (Désiletz et all., 2013).

\section{Pulmonary and Thoracic Anomalies}

About $6 \%$ of NIHF cases correspond to pulmonary and thoracic anomalies (Mardy et al., 2019). Congenital pulmonary airway malformation, congenital diaphragmatic hernia, or congenital airway obstruction syndrome can cause obstruction of blood flow or fetal swallowing of amniotic fluid (Mardy et al., 2019). Congenital pulmonary airway malformations are not specific genetic disorders, but there are genes that affect their development, such as the HOXB-5, FGF-7 and PDGFB genes (Mardy et al., 2019). 
Congenital diaphragmatic hernia is associated with non-immune fetal hydrops in several genetic diseases, such as: Pallister - Killian syndrome, Fryns syndrome and deletions (1p21, 1p12) (Mardy et al., 2019). Congenital airway obstruction syndrome with non-immune fetal hydrops can be found with vertebral defects, anal atresia, cardiac association defects, tracheoesophageal fistula, renal and limb abnormalities, and various rare genetic diseases (Mardy et al., 2019).

\section{Conclusion}

Taking into account the above, it is possible to infer that, in the face of a patient with fetal hydrops, an investigation of the etiology must be immediate, in addition to the immune or non-immune pathological analysis. The causes of non-immune fetal hydrops are diverse, ranging from cardiovascular diseases and gastrointestinal anomalies to chromosomal syndromes and placental disorders. The origin of immune fetal hydrops, on the other hand, may be the result of anemia triggered by erythroblastosis, in addition to an action of minors.

Thus, in cases of immune fetal hydrops, the treatment decision is imperative, and the use of immunoprophylaxis with anti-D immunoglobulin should be ensured, always qualified for the safety of the mother and fetus. In cases of non-immune fetal hydrops, it is essential to identify the exact triggering of the condition, see the vast etiologies, and thus start the treatment.

\section{References}

ABCMED, 2020. Hidropsia fetal - causas, diagnóstico, tratamento, evolução www.abc.med.br/p/saude-da-crianca/1359993/hidropsia-fetal-causas-diagnosticotratamento-evolucao.htm

Alpman A., Cogulu O., Akgul M., et al. (2009) Síndrome de Turner com diagnóstico pré-natal e higroma cístico: incidência e motivos de encaminhamentos. Fetal Diagn Ther 2009; 25: 58-61 (Nível II-2)

Bellini C., Hennekam R. C., Fulcheri E., et al. (2009) Etiologia da hidropisia fetal não imune: uma revisão sistemática. Am J Med Genet; 149A: 844-51 (Nível I)

Bellini, C., \& Hennekam, R. C. (2012). Non-immune hydrops fetalis: a short review of etiology and pathophysiology. American journal of medical genetics. Part A, 158A(3), 597-605. doi.org/10.1002/ajmg.a.34438

Bellini, C., Donarini, G., Paladini, D., Calevo, M. G., Bellini, T., Ramenghi, L. A., \& Hennekam, R. C. (2015). Etiology of non-immune hydrops fetalis: An update. American journal of medical genetics. Part A, 167A(5), 1082-1088. doi.org/10.1002/ajmg.a.36988

Brock, W. W., \& Bradshaw, W. T. (2016). Congenital Chylothorax: A Unique Presentation of Nonimmune Hydrops Fetalis in a Preterm Infant. Advances in neonatal care : official journal of the National Association of Neonatal Nurses, 16(2), 114-123. doi.org/10.1097/ANC.0000000000000257

Cavoretto P., Molina F., Poggi S., Davenport M., \& Nicolaides K. H. (2008). Diagnóstico pré-natal e evolução das lesões pulmonares fetais ecogênicas. Ultrasound Obstet Gynecol; 32: 769-83 (Nível II-2)

Désilets, V., Audibert, F., \& Society of Obstetrician and Gynaecologists of Canada (2013). Investigation and management of non-immune fetal hydrops. Journal of obstetrics and gynaecology Canada : JOGC, 35(10), 923-938. doi.org/10.1016/s1701-2163(15)30816-1

Ek, S., \& Rosenborg, S. (2017). Mesalazine as a cause of fetal anemia and hydrops fetalis: A case report. Medicine, 96(50), e9277. doi.org/10.1097/MD.0000000000009277

Hartge, D. R., Weichert, J., Gembicki, M., \& Krapp, M. (2015). Confirmation of etiology in fetal hydrops by sonographic evaluation of fluid allocation patterns. European Journal of Obstetrics \& Gynecology and Reproductive Biology. Volume 195. 128-132. doi.org/10.1016/j.ejogrb.2015.09.006.

Lee, H. H., Mak, A. S., Kou, K. O., Poon, C. F., Wong, W. S., Chiu, K. H., Au, P. K., Chan, K. Y., Kan, A. S., Tang, M. H., \& Leung, K. Y. (2016). An Unusual Hydrops Fetalis Associated with Compound Heterozygosity for Krüppel-like Factor 1 mutations. Hemoglobin, 40(6), 431-434. doi.org/10.1080/03630269.2016.1267017

Malin, G. L., Kilby, M. D., \& Velangi, M. (2010). Transient Abnormal Myelopoiesis Associated with Down Syndrome Presenting as Severe Hydrops Fetalis: A Case Report. Fetal Diagnosis and Therapy, 27(3), 171-173. 10.1159/000284928

Mardy, A. H., Chetty, S. P., Norton, M. E., \& Sparks, T. N. (2019). A system-based approach to the genetic etiologies of non-immune hydrops fetalis. Prenatal diagnosis, 39(9), 732-750. doi.org/10.1002/pd.5479

Mauad Filho, F., et al. (2002). Tumor placentário diagnosticado durante a gravidez: relato de caso. Revista Brasileira de Ginecologia e Obstetrícia [online]. 24(7), 485-489. doi.org/10.1590/S0100-72032002000700009. 
Oztunc, F., Ugan Atik, S., \& Koka, A. (2016). A case with right atrial appendage aneurysm and hydrops foetalis. Journal of obstetrics and gynaecology : the journal of the Institute of Obstetrics and Gynaecology, 36(7), 850-851. doi.org/10.3109/01443615.2016.1174198

Poeschmann, R. P., Verheijen, R. H., \& Van Dongen, P. W. (1991). Differential diagnosis and causes of nonimmunological hydrops fetalis: a review. Obstetrical \& gynecological survey, 46(4), 223-231. doi.org/10.1097/00006254-199104000-00015

Randenberg A. L. (2010). Hidropisia fetal não imune parte II: a etiologia emfluência da mortalidade? Neonatal Netw; 29: 367-80 (Nível III).

Sanders, R. C. (2002). Structural Fetal Abnormalities, Mosby, Second Edition.

Silva, A. R. A. et al. (2005). Hidropisia fetal: análise de 80 casos. Revista Brasileira de Ginecologia e Obstetrícia [online]. 27(3), 143-148. doi.org/10.1590/S0100-72032005000300008>.

Society for Maternal-Fetal Medicine (SMFM), Norton, M. E., Chauhan, S. P., \& Dashe, J. S. (2015). Society for maternal-fetal medicine (SMFM) clinical guideline \#7: nonimmune hydrops fetalis. American journal of obstetrics and gynecology, 212(2), 127-139. doi.org/10.1016/j.ajog.2014.12.018

Songdej, D., Babbs, C., \& Higgs D. R.; in collaboration with the BHFS International Consortium (2017), An international registry of survivors with Hb Bart's hydrops fetalis syndrome. Blood; 129 (10): 1251-1259. doi.org/10.1182/blood-2016-08-697110

Steurer, M. A., Peyvandi, S., Baer, R. J., MacKenzie, T., Li, B. C., Norton, M. E., Jelliffe-Pawlowski, L. L., \& Moon-Grady, A. J. (2017). Epidemiology of Live Born Infants with Nonimmune Hydrops Fetalis-Insights from a Population-Based Dataset. The Journal of pediatrics, 187, 182-188.e3. doi.org/10.1016/j.jpeds.2017.04.025

Van Den Wijngaard J. P., Ross M. G., \&Van Gemert M. J. (2007). Modelagem de síndrome de transfusão de gêmeos. Ann NY Acad Sci; 1101: 215-34 (Nível III)

Whybra, C., Mengel, E., Russo, A., et al. Lysosomal storage disorder in non-immunological hydrops fetalis (NIHF) - more common than assumed? Report of four cases with transient NIHF and a review of the literature. Orphanet J Rare Dis 7, 86 (2012). doi.org/10.1186/1750-1172-7-86

Yuan S. M. (2017). Cardiac Etiologies of Hydrops Fetalis. Zeitschrift fur Geburtshilfe und Neonatologie, 221(2), 67-72. doi.org/10.1055/s-0042-123825 